\begin{tabular}{c} 
Volume and Issues Obtainable at Center for Sustainability Research and Consultancy \\
Journal of Business and Social Review in Emerging Economies \\
ISSN: 2519-089X (E): 2519-0326 \\
Volume 5: No. 2, December 2019 \\
ᄃSRᄃ \\
Journal homepage: www.publishing.globalcsrc.org/jbsee \\
\hline
\end{tabular}

\title{
Political Stability and the Resolve to Save: The Case of Pakistan
}

\author{
${ }^{1}$ Areeba Khan, ${ }^{2}$ Fatima Farooq, ${ }^{3}$ Sohail Saeed, ${ }^{4}$ Owais Shafique \\ ${ }^{1}$ The Islamia University of Bahawalpur, Pakistan: areeba.khan@iub.edu.pk \\ ${ }^{2}$ Bahuddin Zakariya University Multan Pakistan: fatimafarooq@bzu.edu.pk \\ ${ }^{3}$ The Islamia University of Bahawalpur Pakistan: sohail.saeed@iub.edu.pk \\ ${ }^{4}$ The Islamia University of Bahawalpur, Pakistan
}

\begin{tabular}{l}
\hline \multicolumn{1}{c}{ ARTICLE DETAILS } \\
\hline History \\
Revised format: November 2019 \\
Available Online:December 2019
\end{tabular}

\section{Keywords}

Savings Rate, GDP Growth Rate, Income, Interest Rate, Inflation Rate, Political Stability

JEL Classification:

O16, O47, O49

\begin{abstract}
Savings is potential solution to consume the scarce resources in an efficient way, which helps large scale production, improved productivity of the labor and result in increased economic development. The purpose of this study is to examine how macroeconomic indicators like GDP growth rate, income, inflation rate and interest rate affect gross national savings rate of Pakistan and how political stability influence the relationship between these four macroeconomic indicators and savings rate. Using 10 years macroeconomic data of Pakistan from year 20062015, multiple regression analysis technique was run and it was found that all four macroeconomic indicators significantly affects the savings rate. Income appeared to be strongest predictor in causing an increase in the savings rate. Although GDP found to be have an inverse relationship with savings rate. Political stability appeared to be non-significant in influencing the relationship between macroeconomic factors and savings rate.
\end{abstract}

(C) 2019 The authors, under a Creative Commons AttributionNonCommercial 4.0

Corresponding author's email address: fatimafarooq@bzu.edu.pk

Recommended citation: Khan, A., Farooq, F., Saeed, S. and Shafique, O., (2019). Political Stability and the Resolve to Save: The Case of Pakistan. Journal of Business and Social Review in Emerging Economies, 5 (2), 323334

DOI: $10.26710 /$ jbsee.v5i2.922

\section{Introduction}

Savings is excess of the income over consumption that is not spent immediately and reserved for the future use. Saving is calculated as the difference between disposable income and consumption (Finlay \& Price, 2014). Savings in its simplest form can be in cash or other bank deposits but in the broader form savings can be value of all assets held, including financial assets, inventories, land, land assets, livestock and equipment.

The capacity of an economy to produce is dependent on the gross national income of the country in the long run. Experiences around the globe indicate that countries having high rate of savings, grow more rapidly than low rate of savings and high level of domestic savings are necessary for the fast growth of the capital formation. At macroeconomic level it helps in capital formation and offer leverage for the development of economy and self-sufficiency. Savings are not only important for the economy but they also provide safety cushion to the individuals in case of emergency and make them financially safe and secure. 
Considering the importance of savings at microeconomic and macroeconomic level, determinants or factors affecting the savings rate are considered an important subject of examination. Literature presents many variables which influence savings or are influenced by savings or both. Ando \& Modigliani (1963) provided this Life Cycle Hypothesis ( $\mathrm{LCH}$ ) theory which is based on individuals' household behavior in their different stages of life. From micro level to macro level variables were studied to investigate how those variables impact savings rate of a country.

Major macroeconomic indicators like income, inflation rate, exchange rate, GDP growth and interest rate had positive association with savings in the previous studies of (Bekoe \& Adom, 2013; Duran, Uzgur Duran, Akay, \& Boran, 2017; Niculescu-Aron \& Mihaescu, 2014; Uremadu, 2009; Verter \& Osakwe, 2014). Recent focus of the studies has turned towards the evaluation of behaviroal finance. How human psychology and economic theories together influence the decision of individuals or households savings (Farrell, Fry, \& Risse, 2016; Kapounek, Korab, \& Deltuvaite, 2016). It was also revealed in the study that political stability had an impact on savings directly (Gyimah-Brempong \& Traynor, 1996; Radu, 2015).

Saving behavior is a complex phenomenon of the economic agents. There are several determinants which explain the change in this phenomenon. Macroeconomic indicators like income level, interest rate, GDP growth rate and inflation rate have the major influence on savings.

In literature there is common agreement that people with high income level has more propensity to save as compared to people with low level of income. Inflation also causes surge and drop in savings. Rate of interest has the most effect on savings. Different monetary policies change interest rate in a different manner which further has significant impact on savings. GDP growth rate and savings are also closely related to each other. When GDP is increased disposable income is also increased so people have more to save. Besides macroeconomic agents country's political stability also encourage or discourage the savings done by the general public or households. The more regular the run of the political exchange the more stable it is.1As Pakistan has gone through lots of changing political regimes since 1947 and that seems to become part of Pakistani history. The role of strong military base and Pak armed forces cannot be ignored in shaping economic outlook of Pakistan. Political instability and uncertainty are anathema to a marketbased economy, to fix this problem something had to be done. Strengthening the military was the solution, which even today remains professionally the best institute in the country. 2

The objective of the study is to understand how rate of savings is influenced in Pakistan by the macroeconomic factors. The study also aims to investigate to determine whether the political stability has any impact on the relationship between macroeconomic indicators and savings rate of the Pakistan. The remaining article is organized in four sections, section 2 deals with literature review and provides detail of previous studies on different variables adopted in this article, section 3 discusses the methodology, section 4 present results discussion and last section 5 concludes.

\section{Literature Review}

Business and household savings assist in providing capital for high level of investment which is then used for investing in factories and machineries that nurture economic development. Even different countries use different definitions of the savings. Savings is a flow concept and is measured as residual, stating the

1 The collapse of the government either because of the clash and rambling competition among political parties leads towards the instability of the political environment, see (Ake, 1975).

2 It believed that to bring the reforms to spur the economic development, military had the best interest of the country and knew exactly how to bring those reforms. The removal of the preceding elected government by the military dictator was on the pretext that the elected governments were damaging the economy (Husain, 2010). 
some measures of income minus some measures of consumption as defined by (Statistics New Zealand, 2007). These measures of both income and consumption are defined quite specifically in the national accounts.

\subsection{Does Saving Always Bring Economic Growth?}

Even though the importance of savings for economic growth cannot be ignored but at the same time it cannot be overwhelmed. There is circular flow of the money in the economic activity; earnings of the single individual come from the spending of another individual and vice versa. 3 Countries with access to international capital markets cannot grow rapidly merely by saving more. Because the investment can be financed through foreign savings therefore saving is not an important ingredient in the development of the economy.4 Consumption and spending are the drivers of the economic growth. Keynes (1963) in his book "The General Theory of Employment, Interest and Money" popularized this theorem of the "Paradox of Thrift" stated that during economic recessions individuals try to save more which eventually make aggregate demand to fall and hence economic growth. Such state is detrimental as investment generates lower return than normal.

\subsection{Income and Savings}

In theoretical and empirical literature income growth rate and saving rate has received much attention. Loayza, Schmidt-Hebbel, and Servén (2000) conducted study by taking huge data of 150 countries from the period of 1965-1994. The finding showed that real per capita private disposable income is positively associated with private savings rate. As private agents' income increases and they become richer rate of their savings also increase. The statistical results showed that $10 \%$ increase in income, raises the private savings by $0.47 \%$. However, Carroll and Weil (1994) argued that impact on increase in income level could be negative. They said that other things being equal, forward looking consumers consider them wealthy when there is exogenous increase in growth and those consumers increase their consumption level and save less.

\subsection{Interest Rate and Savings}

An interest rate is the cost of borrowing money. It is typically expressed in terms of percentage of the principal. For the economy, the interest rate of a country is very important. Different studies were conducted to examine the relationship between real interest rate and savings and found positive correlation. Chen (2002) examined the causal relationship between interest rate, income and savings in the Chinese economy. For empirical testing, cointegration test and Bayesian vector auto regression (BVAR) test were used and period of 1952-1999 were included. Test of cointegration revealed that, there exists stable long run relationship between interest rate, income and savings.

\subsubsection{Financial Liberalization}

McKinnon (1973) and Shaw (1973) argued that financial liberalization is an important ingredient in generation of high savings and investment. Liberalization policies did not allow mechanism on interest rates. Against the low interest policy McKinnon and Shaw offered a strong case supported by neoclassical and Keynesian paradigms. According to this framework interest rate, savings, investment and economic growth are positively interlinked with each other. They opposed the ceiling on interest rates.

3 So if one individual is unsure of the future would spend less and start hoarding money and in return make situation worse for the other individual who will also cut his spending. It will stop the economic activity and ultimately economic growth (Shostak, 2001).

4 It was argued by Aghion, Comin, Howitt, and Tecu (2009) that in the developing countries adopting advance technologies through domestic savings is very critical. Frontier technologies are readily adopted by the advance countries but developing countries cannot adopt such frontier technologies with help of outside. 
They debated that financial repression impedes the economic growth. However, interest rate is not always positively affecting the savings rate. 5

\subsection{Inflation and Savings}

Inflation is considered a general enlargement in the price level. In its pessimistic view, increase in inflation increases the opportunity cost of the holding money and being unsure of the future prices it also dampen the investment and savings. Another pitfall of the rapid inflation is the shortage of the goods as consumers start hoarding the goods out of a concern that in future prices will rise (Baloch, 2017). There is also bright side of inflation, as everyone knows money loses its value, a penny worth today will worth less in the future; so inflation gives the incentive of spending and investment.

\subsubsection{Money Illusion Effect}

The money illusion effect is a phenomenon in which people confuse the currency in its nominal terms with real terms. This money illusion effect was presented by Fisher (1928) in his book, "The Money Illusion". With this illusion people ignore the inflation which is taken into consideration by the real prices and income; rather people see money with nominal prices. The purchasing power of the nominal currency is overestimated and consumer decides to increase their real consumption level eventually decreasing the savings.

Miao and Xie (2013) studied how money illusion influences the inflation and long run economic growth. They found that consumption or savings are distorted by the money illusion effect as it effects an agent's observation of the growth and riskiness of real wealth. Long run growth is influenced by this illusion. They further showed that welfare cost of money illusion is insignificant but even with the small degree of money illusion; its impact on long run growth is fairly noticeable.

\subsection{GDP and Savings}

To gauge the health of an economy GDP (Gross Domestic Product) is often used. GDP represents the total value of all the goods and services produced in a country. Najarzadeh, Reed and Tasan (2014) assessed the relationship between savings and GDP. GDP was separated between total GDP and non-oil GDP as Iran is very interest in boosting non-oil sectors of the economy. Period of 1971 to 2009 was taken and an Auto Regressive Distributed Lag Model was used for analysis for causal relationship. The results found positive long run and two way relationship between savings and both types of economic growths (total GDP and non-oil GDP).

According to Sajid and Sarfaraz (2008) relationship between savings and economic growth is not only an important but also a controversial issue. This phenomena is analyzed a cause and effect relationship by many economists. Some economists are in favor of Keynesian theory that savings depend upon the level of output while others believe that savings cause growth. So they carried the study in Pakistan for the period of $1973 / 1$ to $2003 / 4$ to investigate the causal relationship between savings and output using cointegration and vector error correction techniques. Results proposed bi-directional relationship between savings and output level. However results showed unidirectional long run causation from public savings to output (GNP and GDP) and private savings to gross national product (GNP). Overall results supported the point of view that savings cause GDP growth.

\subsection{Political Stability and Savings}

In the earlier studies political stability or instability was studied as dependent variable and focus was to determine the causes of political unrest (Alesina \& Perotti, 1996; Davies, 1969). Later studies took political stability as an independent variable and studied how political instability effects the macroeconomic growth of a country. Aaberge, Liu and Zhu (2016) analyzed the relationship between

5 In their study increase in interest rate, make savings lower and exert negative impact. The test results showed that $1 \%$ increase in interest rate decreases household savings by $0.07 \%$, see (Samantaraya \& Patra, 2014). 
political uncertainty and household savings of China. They studied the household savings and expenditure adjustment to the political shock that occurred in 1989 Beijing, China. Their finding revealed that during political uncertainty there was significant temporary increase in the savings of the urban households of the China. The findings of another research conducted in Bangladesh concluded that political stability has positive effect in the short run but in the long run political stability has negative effect on the economic performance (Ahmed \& Pulok, 2013).

\subsubsection{Mancur Olsen's Theory of Political Stability and Growth}

Mancur Olsen was an American Economist and Social Scientist in his book "The Rise and Decline of Nations: Economic Growth, Stagflation, and Social Rigidities" (1982) challenged the mainstream view by explicitly treating political stability as an independent variable. He claimed in his book that destabilizing and uncertain events observably interrupt economic activities in the short term but he argued that in medium term these events set stage for the rapid economic growth (Olson, 1982).

\section{Methodology and Conceptual Framework}

Based on the ontology of this study it was decided to adopt objective approach as it is more related to quantitative data required for this research. Secondary data is used for this research and collected from multiple secondary sources of internet like databases of World Bank, trading economics, Pakistan Bureau Statistics, reports of the Economic survey of Pakistan and the global economy for different indexes. Sample size chosen for this study is 10 years' time series data from year 2006-2015 of major macroeconomic indicators of Pakistan. Reason behind choosing 10 years sampling frame for this study is that, before 2008 Pakistan had long era of military era of General Pervez Musharraf that cannot be considered as political era. From year 1999-2007, almost 8 years are counted in his era. Therefore, the study chose sampling frame of 10 years, so it would not lose the information. There are four independent variables in this article, income, GDP growth rate, inflation rate, interest rate, one dependent variable savings and one moderating variable that is political stability. IBM SPSS (Statistical Package for the Social Sciences) is used in analysis of the data.

Different proxies have been used for the variables to measure their relationships. Their proxies and descriptions of the variables are given in the Table 1 below.

Table 1: Variable Description

\begin{tabular}{|l|l|l|}
\hline Variable & Title & Operationalization \\
\hline Savings & SAV & Gross National Savings (\% of GDP) \\
\hline GDP & GDP & Real GDP Growth Rate \\
\hline Income & IN & GNI per capita Growth (\%) \\
\hline Inflation & INF & MOM (Month-on-Month) Inflation \\
\hline Interest & INT & Real Interest Rate \\
\hline Political Stability & PS & Vector6 \\
\hline
\end{tabular}

\subsection{Hypothesis Development}

6 Proxy of political stability was used after developing political stability vector in SPSS software by composing five different governance indicators that produced the results for new variable by creating mean sub so called vector. The five governance indicators that used to make vector are political stability index, government effectiveness, political rights, rule of law and civil liberties. Development of the vector is the unique contribution towards this study, as it provides more insight about the worldwide governance indicators. These indexes are available at theglobaleconomy.com. 
Based upon objective of the study both null and alternative hypothesis are developed.

H01: There does not exist a significant relationship between GDP growth rate and savings rate. H02: There does not exist a significant relationship between income and savings rate.

H03: There does not exist a significant relationship between inflation rate and savings rate. H04: There does not exist a significant relationship between interest rate and savings rate.

H05: Political stability does not significantly affect the relationship between macroeconomic indicators and savings rate.

\subsection{Conceptual Framework}

Figure 1 provides the semantic view of different variables and their relationship with each other.

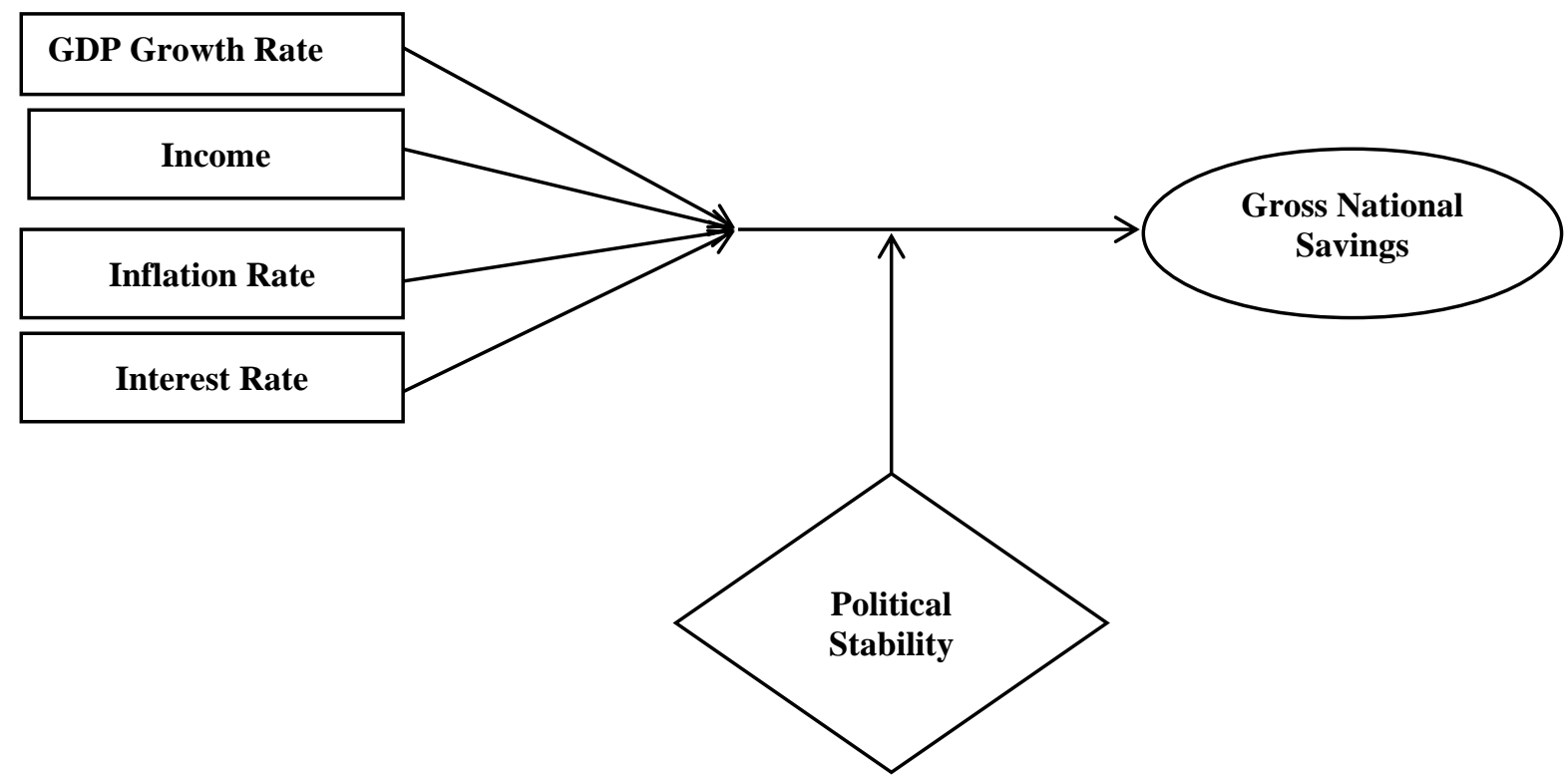

\section{Results and Discussion}

Reliability test is run to ensure that data is consistent. Value of Cronbach' Alpha appeared to be 0.68 , so it is concluded that data is also nearly reliable. 7

Table 2 presents result of correlation analysis. Pearson Correlation was run to check the strength of relationship between variables. In this case, results suggest that except inflation all other independent variables show positive relationship with dependent variable savings. There is negative relationship between inflation and savings that means when inflation increases savings decrease. There is moderate relationship between two -.562. Strongest relationship is between interest rate and savings with Pearson correlation of 0.894 . Relationship is also positive that means with the increase in interest rate savings also increase. Moderating variable political stability is showing the weakest relationship with savings as value of Pearson correlation is only 0.179 , although the relationship is positive.

Table 2 Correlation Matrix

\begin{tabular}{|l|l|l|l|l|l|l|l|}
\hline \multicolumn{2}{|c|}{ GDP } & GDP & INC & INF & INT & PS & SAV \\
\cline { 2 - 8 } & Pearson Correlation & 1 & & & & & \\
\hline
\end{tabular}

7 The value of Cronbach's Alpha comes to 0.68 that is little smaller than the standard value 0.70 proposed by (Nunnally, 1978). 


\begin{tabular}{|c|c|c|c|c|c|c|c|}
\hline & $\mathrm{N}$ & 10 & & & & & \\
\hline \multirow[t]{3}{*}{ INC } & Pearson Correlation & $.972 * *$ & 1 & & & & \\
\hline & Sig. (2-tailed) & .000 & & & & & \\
\hline & $\mathrm{N}$ & 10 & 10 & & & & \\
\hline \multirow[t]{3}{*}{ INF } & Pearson Correlation & -.394 & -.507 & 1 & & & \\
\hline & Sig. (2-tailed) & .260 & .135 & & & & \\
\hline & $\mathrm{N}$ & 10 & 10 & 10 & & & \\
\hline \multirow[t]{3}{*}{ INT } & Pearson Correlation & $.661 *$ & $.778 * *$ & $-.807 * *$ & 1 & & \\
\hline & Sig. (2-tailed) & .037 & .008 & .005 & & & \\
\hline & $\mathrm{N}$ & 10 & 10 & 10 & 10 & & \\
\hline \multirow[t]{3}{*}{ PS } & Pearson Correlation & $.694 *$ & .610 & -.060 & .178 & 1 & \\
\hline & Sig. (2-tailed) & .026 & .061 & .869 & .622 & & \\
\hline & $\mathrm{N}$ & 10 & 10 & 10 & 10 & 10 & \\
\hline \multirow[t]{3}{*}{ SAV } & Pearson Correlation & .590 & $.740 *$ & -.562 & $.894 * *$ & .179 & 1 \\
\hline & Sig. (2-tailed) & .073 & .014 & .091 & .000 & .620 & \\
\hline & $\mathrm{N}$ & 10 & 10 & 10 & 10 & 10 & 10 \\
\hline
\end{tabular}

Table 3A and 3B presents results of regression analysis. While applying this test multiple regression analysis, it is run two times, first without moderating variable and second time with moderating variable to check the significance impact on the relationship between IVs and DV.

Table 3A of regression coefficients shows the sig values for predictor variables. So, we will check it we fail to reject or reject null hypothesis. All sig values are less than 0.05 , it means we reject the null hypothesis and accept alternate hypothesis as developed in section 3 of methodology. 8

Table: 3 A Regression Coefficients

\begin{tabular}{|c|c|c|c|c|c|c|}
\hline \multirow{2}{*}{\multicolumn{2}{|c|}{ Model }} & \multicolumn{2}{|c|}{$\begin{array}{l}\text { Unstandardized } \\
\text { Coefficients }\end{array}$} & \multirow{2}{*}{$\begin{array}{l}\text { Standardized } \\
\text { Coefficients } \\
\text { Beta } \\
\end{array}$} & \multirow[t]{2}{*}{$\mathrm{t}$} & \multirow[t]{2}{*}{ Sig. } \\
\hline & & $\mathrm{B}$ & Std. Error & & & \\
\hline \multirow[t]{5}{*}{1} & (Constant) & 21.528 & .753 & & 28.582 & .000 \\
\hline & GDP & -1.837 & .582 & -1.595 & -3.157 & .025 \\
\hline & INC & 2.607 & .869 & 1.815 & 3.001 & .030 \\
\hline & INF & .822 & .291 & .466 & 2.825 & .037 \\
\hline & INT & .478 & .134 & .913 & 3.558 & .016 \\
\hline
\end{tabular}

8 Four alternate hypotheses, $\mathrm{H} 1, \mathrm{H} 2, \mathrm{H} 3$ and $\mathrm{H} 4$ are accepted, which means, there is significant relationship between GDP and savings, income and savings, interest rate and savings and inflation and savings. 


\section{Regression Equation}

$\mathrm{SAV}=21.528-1.837(\mathrm{GDP})+2.607(\mathrm{INC})+.822(\mathrm{INF})+.478(\mathrm{INT})$

Eq.1A9

The value of $\mathrm{R}^{2}$ in Table 3B is .957 , exhibits that $95.7 \%$ of the variation in savings rate is explained by predictor variables these are income, GDP growth rate, interest rate and inflation rate. R2 is very high which depicts good predictive capacity of the model by explaining such huge variation in the savings rate. One of the reasons for R2 being as high as $95.7 \%$ is attributed to presence of time series data. Secondly, both response and predictor variable have a significant relationship. All the variables are showing significant relationship with response variable because their sig values are less than 0.05 as shown in Table 3A. That's why R2 is very high.

Table 3B Regression Model Summary

\begin{tabular}{|l|l|l|l|l|}
\hline Model & R & R Square & $\begin{array}{l}\text { Adjusted } \\
\text { Square }\end{array}$ & $\begin{array}{l}\text { Std. Error of the } \\
\text { Estimate }\end{array}$ \\
\hline 1 & $.979 \mathrm{a}$ & .957 & .923 & .47421 \\
\hline
\end{tabular}

a. Predictors: (Constant), INT, GDP, INF, INC

Now regression analysis is run again, this time with moderating variable political stability, to check the effect of moderation between IVs and DVs. Results are again presented in two different tables of regression in $4 \mathrm{~A}$ and $4 \mathrm{~B}$.

Results in table 4A shows sig value for political stability is .487 that is greater than criterion value 0.05 . So, we fail to reject $\mathrm{H} 05$ as $\mathrm{F}(4,5)=20.765$, $\mathrm{p}>0.05$. So, it is concluded that political stability does not significantly affects the relationship between four macroeconomic indicators and savings rate.

Table 4A Coefficients

\begin{tabular}{|c|c|c|c|c|c|}
\hline \multirow[t]{2}{*}{ Model } & \multicolumn{2}{|c|}{ Unstandardized Coefficients } & \multirow{2}{*}{$\begin{array}{l}\text { Standardized } \\
\text { Coefficients } \\
\text { Beta } \\
\end{array}$} & \multirow[t]{2}{*}{$\mathrm{t}$} & \multirow[t]{2}{*}{ Sig. } \\
\hline & $\mathrm{B}$ & Std. Error & & & \\
\hline \begin{tabular}{l|l}
1 & (Constant) \\
\end{tabular} & 21.048 & 1.007 & & 20.906 & .000 \\
\hline GDP & -1.968 & .631 & -1.709 & -3.117 & .036 \\
\hline INC & 2.578 & .908 & 1.795 & 2.839 & .047 \\
\hline INF & .863 & 309 & .489 & 2.797 & .049 \\
\hline INT & .524 & .153 & 1.001 & 3.432 & .026 \\
\hline PS & .897 & 1.173 & .122 & .764 & .487 \\
\hline
\end{tabular}

\section{Regression Equation}

$\mathrm{SAV}=21.048-1.968(\mathrm{GDP})+2.578(\mathrm{INC})+.863(\mathrm{INF})+.524(\mathrm{INT})+.897(\mathrm{PS})$

Eq. 1B

9 In regression equation GDP growth rate has negative unstandardized $\beta$, it means any change in the GDP growth rate will cause a decrease in savings rate while other three variables have positive value of $\beta$ any change in interest rate, income and inflation will cause an increase in the savings rate of Pakistan. Income appeared to be the strongest predictor as the value of $\beta$ is highest among all predictors. Change in income will cause the highest increase in savings rate as compared to other predictors. 
Table 4B shows the value of adjusted R2 has decreased from 0.923 to 0.917 .10 When a useful variable is added, value of adjusted R2 is increased but in this case value has decreased that means moderator variable political stability is not a good variable to explain the variation in criterion variable savings.

Table 4B Model Summary of Regression

\begin{tabular}{|l|l|l|l|l|}
\hline Model & $\mathrm{R}$ & R Square & Adjusted R Square & Std. Error of the Estimate \\
\hline 1 & $.981 \mathrm{a}$ & .963 & .917 & .49526 \\
\hline \multicolumn{2}{|l|}{ Predictors: (Constant), PS, INF, INC, INT, GDP } \\
\hline
\end{tabular}

\section{Conclusion}

The above findings and discussion concludes that macroeconomic indicators have significant relationship with the savings rate of Pakistan. Whenever inflation rate, income and interest rate will change, rate of savings will increase. But the when the GDP growth rate will change, savings rate will decrease because GDP growth meant to be heavy investment and more spending as the economy used to be growing up gradually. Eventually savings will decrease.

Results for political stability as a moderator are slightly different than what the literature suggests. Studies in the literature suggest that there is significant and negative relationship between political stability and the rate of savings. Political stability has always been an issue since the independence of the Pakistan. The reason behind these results could be the impact of strong role played by the military of Pakistan. Pakistan became more stable economically because of success in reducing terrorism. Strong military operation like operation Zarb e Azb curtailed terrorism to a great extent and there was a notable decline in terrorists attack in 2015. Although the political situation remained almost same, still the economy started to pick up pace. The most significant development in year 2015 was the establishment of CPEC (China-Pakistan Economic Corridor). During the visit of Chinese President Xi Jinping to Pakistan, US \$46 billion were allocated for the construction of the CPEC, which analysts argue that could be a game changer not only for Pakistan but also for the entire region. Therefore, political scenario is progressively turning out as more stable than before. This could be the reason that political stability may not have a direct influence on the savings rate of Pakistan.

This research did not receive any specific grant from funding agencies in the public, commercial, or notfor-profit sectors.

\section{References}

Aaberge, R., Liu, K., \& Zhu, Y. (2016). Political uncertainty and household savings. Journal of Comparative Economics, 1-17. https://doi.org/10.1016/j.jce.2015.12.011

Aghion, P., Comin, D., Howitt, P., \& Tecu, I. (2009). When Does Domestic Saving Matter for Economic Growth? - HBS Working Knowledge - Harvard Business School (No. 09-080). Harvard Business School. Retrieved from http://hbswk.hbs.edu/item/when-does-domestic-saving-matter-foreconomic-growth

Ahmed, M. U., \& Pulok, M. H. (2013). The Role of Political Stability on Economic Performance: The Case of Bangladesh. Journal of Economic Cooperation and Development, 34(3), 61-100.

Ake, C. (1975). A Definition of Political Stability, 7(2), 271-283. Retrieved from http://www.jstor.org/stable/41410539

Alesina, A., \& Perotti, R. (1996). Income distribution, political instability, and investment. Euorpean Economic Review, 40(6), 1203-1228.

10 When new variable is added in the regression model, value of adjusted $\mathrm{R}$ square is interpreted instead of $\mathrm{R}$ square. 
Ando, A., \& Modigliani, F. (1963). The "Life Cycle" Hypothesis of Saving: Aggregate Implications and Tests. The American Economic Review, 53(1), 55-84. https://doi.org/10.1126/science.151.3712.867-a

Baloch, G. U. (2017). » Impact of inflation on economy of Pakistan. Retrieved August 21, 2017, from http://www.bexpress.com.pk/2017/01/impact-of-inflation-on-economy-of-pakistan/

Bekoe, W., \& Adom, P. K. (2013). Macroeconomic Uncertainty and Private Investment in Ghana: An Empirical Investigation. International Journal of Economics \& Financial Issues (IJEFI), 3(2), 276293.

Carroll, C. D., \& Weil, D. N. (1994). Saving and growth: a reinterpretation. Carnegie-Rochester Confer. Series on Public Policy, 40(C), 133-192. https://doi.org/10.1016/0167-2231(94)90006-X

Chen, C. (2002). Interest rates, savings and income in the Chinese economy. Journal of Economic Studies, 29(1), 59-74. https://doi.org/10.1108/01443580210414120

Davies, J. . (1969). Political Stability and Instability: Some Manifestations and Causes. The Journal of Conflict Resolution, 13(1), 1-17.

Domar, E. D. (1946). Capital Expansion, Rate of Growth, and Employment. Econometrica, 14(2), 137147. Retrieved from http://www.jstor.org/stable/1905364

Duran, E., Uzgur Duran, B., Akay, D., \& Boran, F. E. (2017). Grey relational analysis between Turkey's macroeconomic indicators and domestic savings. Grey Systems: Theory and Application, 7(1), 45-59. https://doi.org/10.1108/GS-10-2016-0039

Farrell, L., Fry, T. R. L., \& Risse, L. (2016). The significance of financial self-efficacy in explaining women's personal finance behaviour. Journal of Economic Psychology, 54, 85-99. https://doi.org/10.1016/j.joep.2015.07.001

Field, A. (2009). Discovering Statistics Using SPSS (3rd ed.). London: Sage. Retrieved from http://www.soc.univ.kiev.ua/sites/default/files/library/elopen/andy-field-discovering-statisticsusing-spss-third-edition-20091.pdf

Finlay, R., \& Price, F. (2014). Discussion Paper Household Saving in Australia.

Fisher, I. (1928). The Money Illusion. New York: Adelphi Company.

Gyimah-Brempong, K., \& Traynor, T. L. (1996). Political instability and savings in Less Developed Countries: Evidence from Sub-Saharan Africa. Journal of Development Studies, 32(5), 695-714. https://doi.org/10.1080/00220389608422436

Harrod, R. F. (1939). An Essay in Dynamic Theory. The Economic Journal, 49(139), 14-33. Retrieved from http://www.jstor.org/stable/2225181

Husain, I. (2010). The Role of Politics in Pakistan's Economy | JIA SIPA. Retrieved August 15, 2017, from https://jia.sipa.columbia.edu/role-politics-pakistans-economy-0

Kapounek, S., Korab, P., \& Deltuvaite, V. (2016). (Ir)rational Households' Saving Behavior? An Empirical Investigation. Procedia Economics and Finance, 39(November 2015), 625-633. https://doi.org/10.1016/S2212-5671(16)30309-4

Keynes, J. . (1963). . “The General Theory of Employment, Interest and Money". Palgrave Macmillan: United Kingdom.

Loayza, N., Schmidt-Hebbel, K., \& Servén, L. (2000). What Drives Private Saving across the World? The Review of Economics and Statistics, 83(2), 165-181. https://doi.org/10.1162/003465300558678

McKinnon, R. . (1973). Money and Capital in Economic Development. Washington, DC, Brooking Institute.

Miao, J., \& Xie, D. (2013). Economic growth under money illusion. Journal of Economic Dynamics and Control, 37(1), 84-103. https://doi.org/10.1016/j.jedc.2012.06.012

Najarzadeh, R., Reed, M., \& Tasan, M. (2014). Relationship between Savings and Economic Growth: The Case For Iran. Journal of International Business and Economics, 2(4), 107-124. https://doi.org/10.15640/jibe.v2n4a7

Niculescu-Aron, I., \& Mihaescu, C. (2014). Modelling the Impact of Economic, Demographic and Social Determinants on Household Saving Rate in the Former Socialist Countries (Central and Eastern Europe). Procedia Economics and Finance, 10(0), 104-113. https://doi.org/http://dx.doi.org/10.1016/S2212-5671(14)00283-4 
Nunnally, J. (1978). Psychometric Theory. McGraw-Hill Book Company, New York.

Olson, M. (1982). The rise and decline of nations : economic growth, stagflation, and social rigidities. Yale University Press. Retrieved from https://books.google.com.pk/books/about/The_Rise_and_Decline_of_Nations.html?id=vKxxtjJz-wC\&redir_esc $=\mathrm{y}$

Pallant, J. (2013). SPSS survival manual: a step by step guide to data analysis using IBM SPSS. Buckingham: Open Press University.

Radu, M. (2015). Political Stability - A Condition for Sustainable Growth in Romania? Procedia Economics and Finance, 30(15), 751-757. https://doi.org/10.1016/S2212-5671(15)01324-6

Sajid, G. M., \& Sarfaraz, M. (2008). Savings and Economic Growth in Pakistan: an Issue of Causality. Pakistan Economic and Social Review, 46(1), 17-36. Retrieved from http://www.jstor.org/stable/25825322

Samantaraya, A., \& Patra, S. K. (2014). Determinants of Household Savings in India: An Empirical Analysis Using ARDL Approach. Economics Research International, 2014, 1-8. https://doi.org/10.1155/2014/454675

Shaw, E. (1973). Financial Deepening in Economic Development. (Oxford, Oxford University Press).

Shostak, F. (2001). Is Saving Bad for the Economy? | Mises Institute. Retrieved August 21, 2017, from https://mises.org/library/saving-bad-economy

Solow, R. M. (1956). A Contribution to the Theory of Economic Growth. Quarterly Journal of Economics, 70(1), 65-94.

Statistics New Zealand. (2007). Measuring Saving in the National Accounts - Statistics New Zealand, (March). Retrieved from http://www.stats.govt.nz/browse_for_stats/economic_indicators/nationalaccounts/measuringsaving-in-the-national-accounts.aspx

Uremadu, S. . (2009). THE IMPACT OF MACROECONOMIC AND DEMOGRAPHIC FACTORS ON SAVINGS MOBILISATION IN NIGERIA. African Review of Money Finance and Banking, 2349. Retrieved from http://www.jstor.org/stable/41410539\%09

Verter, N., \& Osakwe, C. N. (2014). A Time Series Analysis of Macroeconomic Determinants of Household Spending in the Era of Cross-cultural Dynamics: Czech Republic as a Case Study. Procedia Economics and Finance, 12(0), 733-742. https://doi.org/http://dx.doi.org/10.1016/S2212$\underline{5671(14) 00400-6}$ 
